\title{
IN SEARCH OF LIBERATION PEDAGOGY IN SOUTH AFRICA
}

\section{Jonathan Jansen}

On the nature of apartheid education - agreed! The curriculum is racist, Eurocentric, elitist, sexist. Control is central and undemocratic. Students are systematically disempowered and discriminated against. Examinations are culturally biased and racially selective. Classrooms are overcrowded and school buildings are dilapidated. Textbooks are absent, out-of-date, or in need of replacement. Teachers are overburdened, underqualified, and under strict state control. Administrators at "head office" are corrupt, uninterested, and highly authoritarian.

Most of this was already known to me as I started off as a qualified teacher in South Africa in January 1979. After all, I had been a student in "the system." I was there when classmates at my high school burned copies of Moeder Hanna ("Mother Hanna"), a stereotypical portrayal of Blacks during the AngloBoer war which satisfied the perverse desires of white racism. I ran in 1976 when police fired at students for daring to challenge the authoritarian classroom atmosphere. I saw my teachers dismissed for making the mistake of identifying with student grievances. And I remember sitting in a "prefab" dodging the raindrops which fell steadily into this makeshift classroom ("temporary," we were told for five years) while simultaneously reciting Latin tenses.

But if my career as a student made me aware of the defects of a racist education, it was during my experience as a teacher that I started to grasp more fully the meaning of oppression, the legitimacy of alternatives, and the need for struggle.

In this short paper I hope to illuminate the search for liberation pedagogy under apartheid by reconstructing personal experiences of teaching in three different South African high schools.

\section{School A: Introduction to the Politics of Protest}

My first teaching assignment was at a rural school outside of Cape Town in which the dominant form of employment was in the local fishing industry. It was here, in 1979, that I made the transition from student in the system to teacher in the system. As with most Black teachers, I started off with a fairly simple commitment: to be the best teacher to my students. I would raise students' test scores, commit students to learning, make science available to all students, and increase the number of students registering for science at the local universities. Personal concerns about "professional image" loomed large. These goals were, of course, by no means radical. But they represented the starting point for most Black teachers: to do their best for students despite the system. 
The next year, 1980, all hell broke loose in my school and classroom for even though I was recognized as "dedicated" and "hardworking," my message was irrelevant to the students' social context. The way in which students expressed their resistance was not always clearly articulated, sometimes appeared haphazard, often was exploited by a few "comrades,"1 and clearly violated my goals as a beginning teacher. They boycotted school, they used classroom time for political discussion, they marched "in protest against the police presence on school grounds" or "in solidarity with our comrades in Soweto," And this happened at an isolated rural school, where I was often reminded by my colleagues that students here were a different "type" (subservient, uncritical, passive) compared to those in large urban centers like Cape Town.

I made the transition from concerned professional to activist teacher within the next four months. One event, above all, forced the transition. At that moment I saw from the perspective of a teacher something which has come to haunt every Black teacher in South Africa in the past 15 years. On a cloudy Monday morning students were gathered on the campus waiting for the school bell when police surrounded the outside perimeter of the school. As usual, police stormed the campus without warning and for no apparent reason. Students fled. Young standard 6 (eighth-grade) girls were cornered in a classroom. Like wild dogs, the police beat them until they fell. I saw blood, tears. And then those helpless students looked at me, the teacher/guardian/parent-inresidence, as if searching for answers. I stood helpless, my stream of verbal protest having no effect on these sjambok-wielding ${ }^{2}$ thugs called police. I understood then, and in several recurring episodes later, why so many of my colleagues had at such moments of student-teacher-police confrontation made the transition from technocratic teacher to political activist and, on occasion, to comrade in the armed struggle.

\section{School B: From Protest Politics to Awareness Programs}

After two years I left the rural school for one situated in the heart of Cape Town. My new post was at the first Black high school in South Africa, a school which had built up a remarkable tradition of protest against apartheid. Parents, I was often told, sent their children here for "a political education." The names of Betray Kies, Richard Rive, Cosmo Pieterse, Ernie Steenveld, ${ }^{3}$ and many others were cited continually as the best examples of teacheractivists in the struggle against apartheid. In the early 1980s this school was deeply involved in the struggle for justice. But by this time the focus; of student action had turned from mere protest through marchings and boycotts, to the forging of alternative education programs. My students allowed me permission to observe some of these classes because I was deemed to be "progressive." It was during these sessions that I first understood the deep discontent with state pedagogy. My students were among those who expressed the following (quoted in Maurice, 1983):

They decide what we are taught. Our history is written according to their ideas. Biology and Physics are taught in our schools but which we cannot apply to our everyday lives. We are not told that most diseases 
of the workers stem from the fact that they are: undernourished and overworked. We are taught biology, but not in the terms of the biology of liberation, where we can tackle the concept of "race" to prove that there is no such thing as "race." We are taught geography, but not the geography of liberation. We are not taught that $80 \%$ of South Africans are dumped on $13 \%$ of the land. ... We are taught accountancy merely to calculate the profits of the capitalist.

As a result, students embarked on "Awareness Programs" which were primarily designed to raise student consciousness about the evils of apartheid. In addition, students started to take control of their learning. Content was related to their everyday experiences. Interaction was less concerned with using "proper English" or "keeping classroom order" and more focused on the critical questions - why/who says/in whose interests/for what purpose - of liberation pedagogy. To give some concrete examples: the Cape Times was analyzed critically every morning to assess the accuracy of reporting: on the "riots" (state terminology) of the day before; progressive films were shown expressing solidarity with the international workers movement; and featured speakers were brought in from unions to address the comrades.

In this setting, I came much closer to understanding the imperative of resistance as a teacher and more appreciative of the role of students in the struggle. After all, this was a school in the midst of District Six, once a vibrant, culturally rich, and politically active Black area in Cape Town. District Six made world headlines in the 1970s when it fell prey to the Group Areas Act and was officially "reserved" for white residence. I came to the school as the last remaining buildings were being razed. Only the school, the mosque, and the Anglican Church remained. I remember feeling the deepest sense of bitterness as I watched the Black crane driver do his job: knocking down building after building. "This place," recalls the current hit musical District Six, "is reserved for whites," The last verse of the song, by a Black vocalist, never fails to bring a South African audience (normally past residents of District Six) to its feet:

One night when I went to bed
I fell asleep and I had this nightmare
I was dreaming I was dead
I went to hell and the devil was there
He looked at me and he said..."it's alright
This place... is reserved for whites"

At this time I reflected deeply upon my biology teaching. What is the use of teaching students the intricacies of the DNA model when most will never enter a university to explore its structure ? $^{4}$ Or to teach about the beauties of cellular structure when many of them lack the basic health necessities to survive physically under apartheid? Or why bother to teach about the natural balance of the ecosystem when their own ecosystem - District Six - was destroyed mercilessly by the same agents who wrote the textbooks! How could I reduce the textbook-identified factors that "destroy all life" in the South African ecosystem to "modern technology, atomic power, sprays and other poisonous 
substance" (Du Toit et al., 1985, p. 517) when the obliteration of their physical and cultural life in District Six was directly caused by state power and white privilege? And how can I blandly note from the prescribed textbook that "Pigment granules . . . are responsible for the characteristic skin colour of the various races" (Du Toit et al., 1985, p. 440-441) when there is a screaming voice in my conscience that calls on me to explain why they also determine everything else? ${ }^{5}$

But there was a problem. How to teach alternative biology in a system which forestalled such rebellion by instituting a strict and elaborate system of control: school inspectors (later euphemistically called "subject advisors") who sneaked around to make sure every teacher was conforming to the syllabus; centralized examinations, monitored closely by state officials as a reflection of a "successful" school; and teacher assessment measures, linked to promotion, which focused heavily on how their students performed in state examinations. Several of my colleagues were dismissed for refusing to yield. Others, like myself, tried to do both. That is, we tried to prepare students for the examinations while simultaneously injecting alternative forms of thinking, analyzing, participating, questioning, and resisting in the context of apartheid.

By 1985, I became acutely aware of my inabilities as a teacher to develop a liberation pedagogy. After a prolonged period of thinking (was I deserting my students?), I left for the U.S. under a scholarship program chaired by Bishop Desmond Tutu. In the past five years I have been preoccupied with finding ways of developing a liberation pedagogy while completing formal studies in education. I have attended numerous critical theory conferences, organized seminars and conferences on alternative education, and collaborated with Black South Africans in North America to prepare outlines of what a liberation pedagogy could look like against and beyond apartheid. In addition, I voraciously read and continue to explore the works of "critical theorists," consulting Paulo Freire (1970) on the nature of oppressive education, Henry Giroux (1983) on the possibilities of resistance, Donald Spivey (1978) on the transnational character of colonial education (the U.S.-South Africa connection), Angela Davis (1983) on the historical relationship between race, class, and gender, and Cameron McCarthy (1988) on the silencing of race 'within Marxist theories of schooling.

\section{School C: From Awareness Programs to Education for People's Power}

In mid-1987 I returned to South Africa for three months. I was asked by a local principal to teach at a third high school. The scene had changed dramatically. It was the height of state oppression and the height of Black resistance. Qualitatively, things had changed in my science classroom. Students were even more organized in their protest, more aggressive in their resistance, and more committed to personal and social change. I remember a student disappearing from my classroom into police detention. On the day of his release he came to school to continue to learn and to rededicate himself to the struggle. I cautiously introduced several emancipatory elements into my lessons. Here are some examples: 
1. On the social definition of scientific knowledge. Students all over the world tend to see scientific knowledge as universal, neutral, and valid. I would deliberately teach evolution to demonstrate the social selection of biological knowledge, in this case by the Calvinist character of state education ideology. ${ }^{6}$

2. On the racial character of scientific authority. The most widely used biology text in South Africa, Senior Biology for Standards 9 and 10 (Du Toit et al., 1985). is written by eight Afrikaners. This fact opened up the opportunity for critical questions: Was all scientific knowledge "discovered" by whites ${ }^{7}$ What role did white racists play in developing discredited genetic theories of human abilities? ${ }^{8}$

3. On the tentative nature of scientific authority. Scientific revolutions (however "bloodless" they were for Kuhn), with their very human character, illustrate this point powerfully to students. By extension, neither is political authority absolute, permanent, or uncontested.

4. On the cultural exclusion of Blacks from science. When the text, for example, notes that "Our present way of life in this technological age is maintained by large and small enterprises in the field of agriculture, commerce and industry" (Du Toit et al., 1985, p. 547, emphasis added), I ask students to reflect on whether they feel or could demonstrate inclusion in this "our" experience.

5. On the contradiction between the textbook's normative claims and their lived experience. So, when they are called to observe that "To bring about meaningful conservation in South Africa, every inhabitant of the country should be acquainted with the basic principles of ecology" (Du Toit et al., 1985, p. 517), I challenge them to consider who is speaking, and how that principle is violated in their own experience.

6. On the underexplanation of scientific understandings. The clearest case here is to have students reflect on the biology book's claim of "characteristic skin colour"9 and its social consequences.

I took every opportunity to encourage students to use science for social understandings; I developed alternatives to the lecture which empowered students to take charge of their own learning (science projects became an institution $^{10}$; and I selected "facts" from the science textbooks which were clearly scientifically inaccurate to underscore the fallibility of the written word. With apologies to Thomas Kuhn, they learned "normal science" (required for exams) and they practiced "revolutionary science" (required for change).

On the national scene things were changing dramatically. Since 1986 Blacks have defined the purpose of education not simply as "protest" (1976-1980) or "awareness" (1980-1982) but as culminating in the struggle for people's power. The National Education Crisis Committee (NECC) ${ }^{11}$ was spearheading the "People's Education" program on a national basis. The new pedagogy was exemplified in the text What is History? A Guide for Teachers, Students, Community Workers (NECC, 1987). Three specific themes governing People's Education ${ }^{12}$ bear repeating: (1) to redefine curriculum content from its racist, sexist, and classist bias to the emancipatory goals of social relevance, political liberation, and social equity; (2) to restructure classroom relationships from the standard teacher-centered and authoritarian climate to 
a more student-centered, democratic form; (3) to shift political control from both whites and "experts" to Black community initiative. In pockets of schools around the country this new pedagogy was being pursued and elaborated, despite the vicious constraints of state security.

I left South Africa again to continue my personal search for a South African liberation pedagogy and to reflect on the changes forged inside the country through democratic struggles. My journey is and will remain incomplete, for a new pedagogy is never fully defined or programmaticality complete. It is an ongoing, dialectical process which, as new forms of control emerge and changing political climates appear, simply reinforce the need to continue the struggle.

\section{Reflections on Experience}

In this paper I have attempted several things. First, I have told a story. In doing so I have struggled to write in such a way that I break the tension between my structuralist training and the desire to affirm the primacy of human experience. I have utilized the autobiographical method which has recently, albeit in restricted circles, gained some reputation as a form of research and representation [Grumet, 1987; Pinar, 1988; Reiniger, 1988). In presenting this method I strove for "over-orientation rather than alienation," to avoid "losing the self, or regressing to . . . 'paradigmatic rigidity"' (Gunn, 1982). I have also sought to undermine positivist assumptions that human experience can be "known' only by rigid quantifiable measures and with predictable outcomes. Rather than drawing endlessly on the details of personal experience, I have tried to use it as a starting point for further theorizing, a source of information for revealing broader concerns of justice, oppression, and struggle. In this sense the methodology is "grounded" in personal experience.

Second, I have sought to reveal subtle changes in classroom pedagogy in South Africa from 1976 to the present time: from protest politics, to awareness programs, to people's education for people's power. While some would wipe away experience and focus instead on the primacy of structural explanations for opposition in South Africa (Hyslop, 1988; Kallaway, 1984). ${ }^{13}$ I have drawn on students' own experience - both the oppression they have suffered and the creativity they have shown - as a source of resistance.

Third, and related to the above, I have related the experiential moments in the transformation of a teacher from committed professional to classroom activist. I believe that this tells the story of many [though obviously not all) Black teachers as they struggle for a liberation pedagogy in South Africa. It is clear, for example, that students have been a key factor in the shaping of teacher struggles. In spite of having been students ourselves, we have probably learned more: from our students about the school/life connection than the other way round. Such is a humbling experience.

Fourth, I have opened up through retrospection the struggles for liberation pedagogy under apartheid deliberately so as to highlight directions for 
liberation pedagogy after apartheid. If there is one thing that we can learn from postcolonial experiences elsewhere it is that the pedagogy mobilized against colonial rule quickly slips into oblivion during independence. Contrast, for example, the wartime pedagogy of Zimbabwe prior to 1980 (Harber, 1985) and the current postwar pedagogy (Jansen, in press). From programs characterized by participation, productive work, and critical reflection, a pedagogy sets in which restores elitism, conforms to authority, anti stifles critical thinking. ${ }^{14}$ In education, as in politics, South African students, teachers, and parents/workers need to continue the struggle beyond apartheid: to insist on participatory classroom relationships, to constantly interrogate the new pedagogy (whatever form it takes) for its emancipatory potential, to decolonize texts in written and spoken form, to relentlessly "think through" the experiential realities of the people and how they are maintained. In the present South African climate, it may well be timely to stress that liberation education is not negotiable.

Finally, I may be accused by my South African colleagues of romantically portraying student resistance. What about the "thugs" who exploit boycott situations for their own gain? Or the teachers who claim to be radical but come to school late and are behind with work schedules? Or the large scale unemployment exacerbated by constant "stayaways" and "alternative" education rallies? Perhaps I, too, have "Smoke in my Eyes." ${ }^{15}$ Clearly the meanings of resistance require further reflection and theorizing in the South African context. I have simply tried to provoke a much-needed alternative discourse in South Africa which begins with the understanding that

the causes and meaning of oppositional behavior ... have little to do with the logic of deviance, individual pathology, learned helplessness (and, of course, genetic explanations), and a great deal to do, though not exhaustively, with the logic of moral and political indignation. (Giroux, 1983, p. 107)

I gladly acknowledge the constructive comments of my colleagues Bruce King and Dan Perlstein on an earlier version of this paper.

\section{Notes}

1. The term "comrades" is increasingly used in the townships to refer to progressive Black activists. It was also useful in that it could replace the first name thereby suppressing the identity of the activist in public meetings.

2. A sjambok (Afrikaans) is a leather whip which leaves deep red scars on the skin. It can cause lasting damage especially when used to hit in the face.

3. These were teachers who in the past four decades had led the struggle against racially divided educational administrations and, indeed, against the entire racist political system. While they have all since retired, moved into exile, or gone on to teach at colleges and universities, they left an indelible mark on subsequent generations of teachers and students at this Cape Town school. 
4. One of the most effective ways to prevent students from entering university is through the state's policy of curriculum "differentiation," similar to tracking in the United States. Since most students are "tracked" into "standard grade" classes, especially in science and math, their chances of entering university are effectively reduced. While this policy is accompanied by a tempting educational logic ("'catering for the diverse needs and abilities of students"), it is more powerfully interpreted as a method of political control (see Jansen, 1990).

5. Those familiar with the style of these questions will recognize that I am turning the apartheid rhetoric on itself. "Why teach a black child mathematics when it can never use it in practice?" said apartheid architect Hendrik Verwoerd.

6. Official state education ideology in South Africa is misleadingly called Christian National Education (CNE). This ideology upholds the racial superiority of whites and argues against the equal participation of Blacks in the social and economic life of the country (see Enslin, 1984 and Beard \& Morrow, 1981 for a critique of CNE). The exclusion of evolutionary biology from the science syllabus is a direct function of the "Christian" interpretation which assumes the miraculous creation of man [sic] by a single act of God.

7. Ivan van Sertima's (1983) Blacks in Science is a most valuable reference on the historical contribution of Africans in science.

8. An excellent practice-based approach to understanding racist science and developing an antiracist science curriculum is found in Gill and Levidow's (1987) edited book.

9. See the quotation from a standard science textbook in South Africa earlier in this paper.

10. The annual science fair allowed students to develop their own models of a scientific phenomenon using materials from the local community and to engage the assistance of parents in constructing the models. These models were never "right" or "wrong"; rather, emphasis was placed on how these constructions reflected students' understandings of the science-society connection.

11. The NECC was formed in the mid-1980s as a direct response to the intense political suppression of schools and society under the "state of emergency? This national organization was a truly democratic forum led mainly by teachers (often those who were expelled from the profession for aggressively rejecting state' control in Black education but also involving parents and students in the decisionmaking processes of the committee and in the development of the "People's Education" curriculum materials.

12. This is not the place to provide yet another detailed account of People's Education. For those interested, see Jansen (1989), Shafer (1989) and Walters and Kruss (1989). 
13. Kallaway's (1984) landmark contribution was the first comprehensive Marxist interpretation of education in South Africa. However, the volume is severely handicapped by its emphasis on "the needs of the productive and political systems" (p. 6). Similarly, Hyslop (1988) reflexively relates all educational developments to "specific socio-political conjuncture" (p. 183) in the apartheid system. Both contributions fail to deliver school-and classroomlevel analyses of repression, resistance, and reconstruction as a point of departure for critical theorizing.

14. I use critical thinking here not in the narrow sense of intellectual acrobatics or the mastery of cognitive skills, but in the sense of reflection which creatively and consistently runs between personal lived-experience and broader social oppression.

15. The term is used by David Gilmour (1989) to critique the "monolithic explanation" (p. 367) of a prominent case study of resistance in South African education where, "although the text is rich with eye-witness reports from the front-lines, the smoke of battle tends to obscure the larger picture" (p. 368).

\section{References}

Beard, P. N. G., \& Morrow, W. E. (1981). Problems of pedagogics: Pedagogics and the study of education in South Africa. Durban: Butterworths.

Davis, A. (1983). Women, race and class. New York: Random House.

Du Toit, J. J., et al. (1985). Senior biology for standards 9 and 10 (Vol. 2). Goodwood, Cape Town: NASOU Limited.

Freire, P. (1970). Pedagogy of the oppressed. New York: Seabury.

Gill, D., \& Levidow, L. (1987). Anti-racist science teaching. London: Free Association Books.

Gilmour, D. (1989). Smoke in your eyes: A comment on 'Students take control: The 1980 boycott of coloured education in the Cape Peninsula.' British Journal of Sociology of Education, 10(3). 367-374.

Giroux, H. (1983). Theory and resistance in education: A pedagogy for the opposition. South Hadley, MA: Bergin \& Garvey.

Grumet, M. (1987). Personal knowledge. Curriculum Inquiry, 17, 319-329.

Gunn, J. (1982). Autobiography: Towards a poetics of experience. Philadelphia: University of Pennsylvania Press.

Harber, C. (1985). Weapon of war: Political education in Zimbabwe. Journal of Curriculum Studies, 17(2). 163-174. 
Hyslop, J. (1988). School student movements and state education policy: 1972-1987. In W. Cobbett \& R. Cohen (Eds.). Popular struggles in South Africa (pp. 183-209). Trenton, NJ: Africa World Press.

Jansen, J. (1989). Contending curriculum orientations in South Africa: The challenge to apartheid. Perspectives in Education (India), 5(3), 125-133.

Jansen, J. (1990). Curriculum as a political phenomenon: Historical reflections on Black South African education. Journal of Negro Education, 59(2), 195206.

Jansen, J. (in press). The state and curriculum in transition societies: The Zimbabwean experience. Comparative Education Review.

Kallaway, P. (1984). Apartheid and education: The education of Black South Africans. Johannesburg: Ravan Press.

Maurice, E. (1983). The curriculum and the crisis in the schools. In A. P. Hunter, M. J. Ashley, \& C. J. Millar (Eds.). Education, curriculum and development (pp. 99-121). Cape Town: University of Cape Town.

McCarthy, C. (1988). Slowly, slowly, slowly the dumb speaks: Third World popular culture and the sociology of the Third World. Journal of Curriculum Theorizing, 812), 7-21.

NECC [National Education Crisis Committee]. (1987). What is history? A guide for teachers, students, community workers. Johannesburg: Skotaville Press.

Pinar, W. (1988). Whole, bright, deep with understanding: Issues in qualitative research and autobiographical method. In W. Pinar (Ed.), Contemporary curriculum discourses (pp. 134-153). Scottsdale, AZ: Gorsuch Scorisbrick.

Reiniger, M. E. (1988). Autobiographical search for gyn/ecology: Traces of misogyny in women's schooling. Journal of Curriculum Theorizing, 8(3), 7-21.

Sertima, I. van (1983). Blacks in science: Ancient and modern. New Brunswick, NJ: Transaction Books.

Shafer, S. (1989). People's education in South Africa. International Journal of Social Education, 4(2), 60-68.

Spivey, D. (1978). Schooling for the new slavery. Westport, CT. Greenwood Press.

Walters, S., \& Kruss, G. (1989). People's education in South Africa. Journal of the African Association for Literacy and Adult Education, 4(1), 2-7. 
JONATHAN JANSEN is a science teacher from South Africa and is currently completing doctoral studies in international development education at Stanford University. He has published several articles on the state and curriculum in the third world in journals such as Comparative Education Review, International Journal of Educational Development, and Oxford 